\title{
THE ROLE OF WOMEN IN THE CHURCH AND IN CHRIST APOSTOLIC CHURCH IN PARTICULAR
}

\author{
Eva Shaw-Taylor \\ Institute for Diasporan Culture \\ New York
}

No tree can form a Forest

\begin{abstract}
The Christ Apostolic Church (CAC) describes itself as a "distinctly indigenous African Church and by its structure, belief and practices, it is an independent Pentecostal church". In reading through the origins of the CAC Worldwide (Nigeria) and the CAC International, this writer was struck by certain similarities to the beginnings of the evangelization of Christianity and the Apostle Paul. Starting with the histories of the two churches, this research will seek to examine the similarities, or the lack thereof, of the role women have played in advancing the visions and missions of the two Apostolic Churches as they also did for St. Paul and the Early Church. It will also look at the transnational significance it holds for the Diaspora where women's issues are placed in the forefront on church issues.
\end{abstract}

Key Words: Evangelism; Prophecy; Revivalism; Sanctification; Subjugation

\section{Introduction}

\section{Christ Apostolic Church Worldwide of Nigeria}

The Christ Apostolic Churches claim today to be the first Pentecostal churches in West Africa. The movement emerged in both Nigeria and Ghana under strong African leadership with transnational connections to the United States and England. Today both churches continue to be characterized by significant transnational connections, having their headquarters in West Africa while maintaining a presence throughout the African Diasporan world.

The Pew Forum on Religion and public Life in 2006 funded a project on the Historical Overview of Pentecostalism in Nigeria. This research was organized into different periods stretching from origins and growth, and the Islamic period through 2006. The PEW research dates the origins of Pentecostalism from 1910 when an Anglican deacon launched an indigenous prophetic movement that later became the Christ Army Church. Early Aladura churches inside the Eternal Sacred Order of the Cherubim and Seraphim Society were founded in 1925 and the Church of the Lord (Aladura) was founded in 1930. Around 1918, an Anglican formed a prayer group known as the Precious Stone Diamond Society to heal influenza victims. This group joined the Faith Tabernacle, a Philadelphia-based Church in the early 1920s. ${ }^{1}$

Anderson 2001:80-82; Gaiya 2002:5. http:// www.pewforum.org/2006/10/05/historical-overview-of-

pentecostalism-in-nigeria, accessed July 9, 2011. 
The research also covered the 1930s and 40s when the Joseph Babalola of Faith Tabernacle lead a revival that converted thousands of people; this group initiated ties with the Pentecostal Apostolic Church of Great Britain. However, this association was dissolved over the use of modern medicine and in 1941 Babalola founds the independent Christ Apostolic Church.

The history of the founding fathers of Christ Apostolic Church tells of two distinct but similar experiences by two ordinary working men whom Christ chose to speak to just as he spoke to the early Christian Apostles like Peter, James and John. Matthew, a tax collector and Saul, a highly educated man who was responsible for the persecution of the early Christians but who chose to obey the Lord's call, are all examples of people of faith who chose to leave their profession to follow their 'call'. We will begin with the history of the founding father of CAC worldwide, Joseph Ayodele Babalola.

The CAC Worldwide derives its doctrine from the Holy Scriptures and the beliefs of the founding fathers. The history of the Church is traceable directly to their forefathers, namely Oba/Pastor Isaac Babalola Akinyele, Pastor David Ogunleye Odubanjo, Joseph Sadare, Miss Sophia Odunlami and Evangelist (late Apostle) Joseph Ayodele Babalola who was called to the ministry by the Lord on 11 October 1928. Apostle Babalola's call subsequently led to the great revival of 1930. Babalola was born of Yoruba parents at Ilofa, Nigeria, and was brought up as an Anglican. Having left elementary school, he was employed in the Public Works Department as a steam roller operator. In October 1928, while trying to repair his machine, he believed that Jesus Christ called him to abandon the job and start preaching. He then joined the Faith Tabernacle in Lagos, which was related to an American Pentecostal organization. ${ }^{2}$

In September 1930 Babalola was credited with raising a dead man to life. From then on, with bell and Yoruba Bible in hand, he toured Yoruba land and eastern Nigeria, preaching about repentance, renunciation of idolatry, the importance of prayer and fasting, and the power of God to heal sickness. In 1930 Faith Tabernacle became affiliated with the British Apostolic Church. Then following a schism in the Apostolic Church round about 1940, Babalola went with a new independent church, Christ Apostolic Church Worldwide (CAC), where he continued his healing and revivalist activities until his death. ${ }^{3}$ The CAC Worldwide regards Babalola as an apostle and his revival ministry as the beginning of the church. A CAC Worldwide retreat centre was built where Babalola was first called in 1928. The CAC Worldwide believes in the efficacy of prayer and that no divine healing could be achieved without faith and trust in Jesus Christ. As a Pentecostal denomination, the Church by the guidance of the Holy Spirit is administered by the orders of Apostle, Prophets, Evangelists, Pastors and teachers. The church has an impelling message of worshipping in a truly African pattern for all Nigerians. ${ }^{4}$

\section{Christ Apostolic Church International of Ghana}

Almost around the same period, a similar transformation was happening in Ghana. Apostle Peter Newman Anim was born on 4 February 1890 to Mr Simon Appiagyei and Madam

\footnotetext{
Elijah Olu Akinwumi "Dictionary of African Christian Biography” p.1. http://www.dacb.org/stories/nigeria, accessed July 9, 2011.

History of CAC Worldwide. http://www.cacworldwide.net/history, accessed July 9, 2011.

4 History of CAC Worldwide.
} 
Hannah Lartebea of Boso in the Volta Region of Ghana. He attended the Basel Mission School at Anum. In 1911 he joined his brother at Amonokrom (Akuapem) and assisted him in his carpentry workshop. Later in the same year he left this town for Pakro to work with the Basel Mission Factory as a weighing clerk. However, he left this job in 1912 due to ill health. In 1914 he became a bricklayer.

In 1917 Anim took an interest in a religious periodical, The Sword of the Spirit, which was in circulation in the country. This magazine was edited by Pastor A Clark, founder of the Faith Tabernacle ministry, Philadelphia. The Faith Tabernacle was not a Pentecostal organization but it had strong emphasis on faith healing and holiness. This kind of emphasis seemed entirely different from anything Anim's Presbyterian upbringing had taught him. He found the teachings in this magazine 'a real blessing' because, as he put it, "though I had intellectually believed the Bible before, I never had the truth presented in a more realistic way..." One of the teachings of the Faith Tabernacle of Philadelphia was its emphasis on 'prevailing prayer.'

In 1920, following the death of his wife, he was converted 'into the faith.' The Faith Tabernacle was linked to the Precious Diamond Society of Nigeria of which Babalola was a member, and it was upon the Faith Tabernacle that Babalola founded his independent Christ Apostolic Church in Nigeria.

Anim had been suffering from chronic stomach trouble his whole life. In 1921 he also developed guinea worm disease. He then decided to put into practice Clark's teachings on healing. To his delight he was simultaneously healed from the worm attack as well as his chronic stomach disease. He therefore resigned from the Boso Presbyterian Church after his divine healing in 1921. After the healing of the first sick person who went to Anim's group, the news of his recovery spread, and so several sick people were brought to the group for healing. ${ }^{6}$

The healing and evangelistic activities of Anim's group attracted the attention of the then traditional chief of Asamankese, Nana Kwaku Amoah. Consequently, he offered them a parcel of land upon which they constructed their first new church building. By 1923 Anim's movement had seen considerable growth. Pastors and elders were therefore ordained by Clark to assist him in 1924. Anim tells us that "the truth had spread like fire. Churches were founded in Akwapem, Kwahu, Ashanti, Coaltar, Asuokyene, Pampanso, Teshie, Nungua, Keta, Anlo, Togoland and other places with God's blessing."7

Another event which seems to have increased the faith of Anim and also added more people to the group, took place in May 1923 during a revival meeting. At the close of service, it was reported that several Christians and non-Christians saw what was believed to be the glory of God in the form of a 'Pillar of Fire' on the top of the church building. ${ }^{8}$ Baptism by immersion appears to be one of the cardinal teachings of Clark, so he requested Anim to take immediate steps to fulfill its requirements. Anim established a formal relationship with Clark in 1923 when he received a certificate of ordination from Clark.

Anim was therefore baptized by immersion on 3 December 1923 by IL Bennett (one of Anim's leaders) from Larteh Akuapem. Anim in turn baptized Bennett the same day. It is

Peter Anim, n.d. The History of How the Full Gospel Church was founded in Ghana. (Accra: CAC) p.1

6 Kingsley Larbi,'Dictionary of African Christian Biography” p.1. http://www.dacb.org/stories/ghana, accessed July 9, 2011.

Anim, The History, p.3.

8 Anim, The History, p.2. 
not clear what role this sacrament played and the form it took in the Faith Tabernacle. Anim indicates that his baptism by immersion was not taken kindly by all and that some under the leadership of one Amoah, 'filled with envy' decided to break away because of this act and left for Finte in the mid-Volta area. This group, described by Anim as the 'lost sheep,' later returned. ${ }^{9}$

In spite of this overwhelming success of Anim's evangelistic activities, he did not ordain any worker into the ministry until he had received the certificate of ordination from Clark in August 1923. This was perhaps due to Anim's theological understanding that, though one's call into the ministry comes first and foremost from God, this call must be recognized by man. Ordination certificates therefore did not serve as an evidence of spiritual authority, but rather as a sign of recognition by man of the one whom God had chosen.

In 1923 the extent of work and the need for workers became clear to Anim. To take care of this need, a meeting was arranged at Winneba in the Central Province, between 28 December 1923 and early January 1924. During this meeting, the church at Winneba was opened officially, pastors were ordained, and elders were anointed for the work. ${ }^{10}$ So the Christ Apostolic Church of Ghana was established officially in 1923-1924. Anim embarked on intensive evangelistic activities which saw the rapid spread of the work.

A major event which increased the publicity of Anim's organization was the outbreak of the phenomenon referred to as 'Holy Ghost Outpouring.' Anim's faith was buttressed when a member of his organization experienced the phenomenon of Spirit baptism in 1932. Stephen Owiredu, a member of Anim's group, went into the bush at his Brekumanso village farm which is near Asamankese, to pray for one of his twin babies who was ill. It was during the prayers that he had the extraordinary experience which Pentecostals referred to as the baptism of the Holy Spirit. When this news reached Anim at Asamankese, he and two brothers, Danso and Abokyi, and two sisters, Comfort Nyakoah, and Oparebea, went to the village. A prayer meeting was held at the village during which two sons of Owiredu and the two sisters who accompanied Anim received the experience. ${ }^{11}$

After this encounter at Brekumanso, Anim and his entourage returned to Asamankese to launch one of their greatest revivals, between 31 August and 12 September 1932. Anim recalled that at these meetings a great number of our Sisters received the mighty Baptism of the Holy Ghost, speaking in tongues, prophesying together with the manifestation of various signs of the Apostolic promises, Acts:1-4; 10:44-46. Prayer was continued and the Sisters filled with the Holy Ghost were moved to lay hands on the Brothers and some were baptized by the Holy Ghost. "Brother Owiredu (Junior) and I, received sanctification during the process of the Revival Prayer Meetings":

Since that date, continuous tarry meetings were held and many people received marvellous healing (by Divine power) and God confirmed His Word with signs following. Here we realized in fact our paramount call to be the Apostles of the Faith as recorded in St. Mark 16: 15-20, and from that period the name of the Church had a worldwide fame. People who were hungry for the deeper spiritual experience and desirous of receiving the power from on high... arrived from far and near in search of the Holy Ghost Baptism. As a result of practical demonstrations of the work of the Spirit as in the days of the

\footnotetext{
9 Anim, The History, p.2-3.

10 Anim, The History, p.3.

11 Anim, The History, p.5
} 
Apostles and testified by public, many were converted and received the Baptism of the

Holy Ghost and left [for] their various towns and villages - propagating the good tidings. ${ }^{12}$

At this point Anim is said to have 'received sanctification.' Apostle Mika Asamoah, a onetime personal assistant to Anim, has indicated that Anim did not experience the Spirit baptism at this time, and that he experienced it some years later. ${ }^{13}$ The church enjoyed considerable growth because of this experience of Spirit baptism. This feature of the church attracted some Christian leaders in the other churches. This period was known as the Holy Ghost Dispensation period among Anim's group. Anim indicated that the revival of 1932 spread to Ashanti, Togoland, Anlo (Awuna), Fanti, some towns in the Eastern Region, and many other parts of the country. ${ }^{14}$

It is interesting to note here that a similar controversy with the Apostolic missionaries took place at the same time in Nigeria between 1939 and 1940. George Perfect, superintendent of the Apostolic Church, admitted taking a daily dose of quinine as a prophylactic against malaria, a practice which led to the separation of a number of assemblies in the Lagos area from the Apostolic Church in April 1940. The breakaway faction was led by DO Odubanjo, the leading African Apostle of the Apostolic Church in the Lagos. This group, after adopting various names, finally decided to adopt the name, Christ Apostolic Church in 1942. ${ }^{15}$ Babalola joined the independent group to continue with his evangelistic work. Peel gives 13 July 1941 as the date this name was adopted, though he mentions that the "church was formally incorporated on 4 May 1943."16 Since the Faith Tabernacle years, the CAC in Ghana and the CAC in Nigeria have been in close fellowship, founding a cordiality which continued till the deaths of the early leaders.

The story of the conversion of Saul as told in Acts 9 is well known to many Bible readers. Even though the conversions of the two founding fathers of the CAC were not the same in their works prior to their calling, all three were called and became evangelists and took up the mantle for Christ. There were schisms in the evangelical pursuits of all three evangelists. However, one finds that Paul's letters have been used to justify a whole lot of 'negatives' against different classes of mankind. In their book, The First Paul, authors Borg and Crossan state that Paul is second only to Jesus as the most important person in the origins of Christianity, yet he is not universally well regarded, even among Christians: some find him appealing while others find him appalling. ${ }^{17}$

The book of Philemon reflects Paul's view that once a slave becomes a Christian, he becomes a 'brother' and is no longer a slave. And in Galatians 3:26-29, Paul states:

${ }^{26}$ So in Christ Jesus you are all children of God through faith,

${ }^{27}$ for all of you who were baptized into Christ have clothed

\footnotetext{
Anim, The History. p.6

Larbi, Dictionary

Larbi.

5 SG Adegboyega and IJVaughan, Short History of the Apostolic Church in Nigeria, cf., 1991. Nigeria: Origins of Apostolic Church Pentecostalism, 1978:135.

16 JDY Peel, Aladura: A Religious Movement among the Yoruba. London: International African Institute, 1968:64.

17 Marcus J Borg and John Dominic Crossan, The First Paul. New York: HarperCollins, 2009:1.
} 
yourselves with Christ. ${ }^{28}$ There is neither Jew nor Gentile, neither slave nor free, nor is there male and female, for you are all one in Christ Jesus. ${ }^{29}$ If you belong to Christ, then you are Abraham's seed, and heirs according to the promise.

Paul has been credited with this biblical defense of slavery in Ephesians 6:5-8 and again in Colossians 3:22-25. Ephesians 6:5-8:

${ }^{5}$ Slaves, obey your earthly masters with respect and fear, and with sincerity of heart, just as you would obey Christ. ${ }^{6}$ Obey them not only to win their favor when their eye is on you, but as slaves of Christ, doing the will of God from your heart. ${ }^{7}$ Serve wholeheartedly, as if you were serving the Lord, not people, ${ }^{8}$ because you know that the Lord will reward each one for whatever good they do, whether they are slave or free.

Colossians 3:22-25:

${ }^{22}$ Slaves, obey your earthly masters in everything; and do it, not only when their eye is on you and to curry their favour, but with sincerity of heart and reverence for the Lord. ${ }^{23}$ Whatever you do, work at it with all your heart, as working for the Lord, not for human masters, ${ }^{24}$ since you know that you will receive an inheritance from the Lord as a reward. It is the Lord Christ you are serving. ${ }^{25}$ Anyone who does wrong will be repaid for their wrongs, and there is no favouritism.

Paul has also been credited with this view on the subjugation of women in 1 Timothy 2:9-15:

${ }^{9}$ I also want the women to dress modestly, with decency and propriety, adorning themselves, not with elaborate hairstyles or gold or pearls or expensive clothes, ${ }^{10}$ but with good deeds, appropriate for women who profess to worship God. ${ }^{11}$ A woman ${ }^{[a]}$ should learn in quietness and full submission.

${ }^{12}$ I do not permit a woman to teach or to assume authority over a man; ${ }^{[b]}$ she must be quiet. ${ }^{13}$ For Adam was formed first, then Eve.

${ }^{14}$ And Adam was not the one deceived; it was the woman who was deceived and became a sinner. ${ }^{15}$ But women ${ }^{[\mathrm{c}]}$ will be saved through childbearing - if they continue in faith, love and holiness with propriety.

And again in 1 Corinthians 14:34-36:

${ }^{34}$ women should remain silent in the churches. They are not allowed to speak, but must be in submission, as the Law says. ${ }^{35}$ If they want to inquire about something, they should ask their own husbands at home; for it is disgraceful for a woman to speak in the church. ${ }^{36}$ Did the word of God originate with you? Or are you the only people it has reached?

In an effort to understand Paul better, many theologians have studied the New Testament thoroughly - including Marc Borg and John Crossman. They state that a) not all letters 
attributed to Paul were written by him, b) Paul's letters have to be placed in their historical context and c) that Paul is best understood as a Jewish Christian mystic and that his message is grounded in his life-changing and sustaining experience of the risen Christ. ${ }^{18}$

After many studies and by scholarly consensus and with hermeneutics at work, seven letters are supposed to be genuinely written by Paul - Romans, 1 and 2 Corinthians, 1 Thessalonians, Galatians, Philippians and Philemon. Three pastoral letters 1 and 2 Timothy and Titus were written around the year 100, possibly a decade or two later, and were attributed to Paul, as was the common practice at that time. There authorship of Ephesians, Colossians and 2 Thessalonians are disputed. ${ }^{19}$

So there is the possibility that the passages attributed to Paul about slavery may not have been written by him, or the passage in 1 Timothy, but what about what he wrote about women in 1 Corinthians? The last verse struck a chord in me: ${ }^{36}$ : Did the word of God originate with you? Or are you the only people it has reached? It is almost as if there is some jealousy being portrayed here because of the pivotal part women played in the expansion and evangelization of the early Christian church. This is surprising because in Paul's letter to the Philippians, we see how much he respected Lydia, whose work in the Church he clearly recognized.

\section{Women in the Early Christian Church}

In his book What Paul Really Said About Women, John Temple Bristow attributes the Greek legacy of disdain for women, for the influence it had on the writings around this time. Egyptian women appeared in public as merchants in the public market place or on the picket line supporting their husbands in the first recorded labour strike in history. ${ }^{20}$ Hermeneutics again played a part in the way the earlier writings have been portrayed. Cultural bias may also have played a part in the misinterpretation of Scripture.

Paul made four statements that contradict the Genesis account to degrade women: First: woman is the glory of man - she is not the distraction of men nor an object to be owned or used, as the Greeks believed, but the very glory of man. Second, in 1 Corinthians 11:9 Paul states: Neither was the man created for the sake of the woman, but the woman for the sake of the man. What Paul was saying is that men need women. Women are not created just for the purpose of bearing and rearing children. As God observed in Genesis: It is not good that man should be alone (Gen. 2:18): the stoic disdain for women is unrealistic and unnatural. ${ }^{21}$ Third, Paul opposed the exclusion of women in worship and the synagogue practice of relegating women to a side chamber or a balcony as silent observers of the men at worship. Paul challenged the notion that women were inferior to men because Eve was created out of Adam; because as he observed that every man alive came out of woman (born of woman) so if Eve was inferior to Adam by virtue of being made out of his body, then every man is inferior to his mother for the same reason. ${ }^{22}$

\footnotetext{
8 Marcus J Borg and John Dominic Crossan, The First Paul. New York: HarperCollins, 2009:13.

9 Borg and Crossan, p.14

20 John Temple Bristow, What Paul Really Said About Women. San Francisco: Harper \& Row Publishers, 1988:11.

21 Bristow, p.59

22 Bristow, What Paul Really Said About Women, p.60
} 
There is evidence that there were women preachers, pastors, prophets and patrons. There are women saints on the Prudentiana and Praxedis mosaic depicting two saints, Mary and a fourth woman whose hair was veiled and whose head is surrounded by a square haloan artistic technique indicating that the person was still living at the time the mosaic was made. There is an inscription stating Theodora Episcopa meaning Theodora, Woman Bishop. $^{23}$

I Corinthians 14:36: Did the word of God originate with you? Or are you the only people it has reached? Maybe the word of God originated with the women; after all in the Gospel according to Mary, a gnostic Gospel, it was Mary Magdalene who rallies the despondent disciples after the ascension of the Lord. By exhortation, encouragement and finally a rousing sermon on the teachings of Jesus, she revives their flagging spirits and sends them off on their mission. Historical evidence such as this, from art, inscriptions, and literature belongs to the hidden history of women's leadership, a history that has been suppressed by the selective memory of succeeding generations of male historians. ${ }^{24}$ Maybe the word resonated with the women more than the men. Maybe the women understood the word better than the men as in the story of the woman who anointed Jesus and was berated by his disciples in Mark 14:3-5.

There were several women in leadership positions - to name a few - a business woman, financially independent and the ruler of her household, Lydia, Theopempte, Priscilla. The church at Phillipi was not only founded by a woman but its leadership continued in the hands of women. ${ }^{25}$ According to Roger Gryson in his book The Ministry of Women in the Early Church, from the beginnings of Christianity, women assumed an important role and enjoyed a place of choice in the Christian community. Paul praised several women who assisted him in his apostolic works. Women also possessed the charisma of prophecy. ${ }^{26}$

Prophetic leadership was important in the beginning of the new Church; prophesying was one of the vital forms of leadership in early Christianity. Apostles, prophets and teachers constituted the trio of leaders Paul mentioned in his writings. Apostles were the travelling evangelists, whose work took them from city to city, spreading the good news of Jesus' life, death and resurrection. There were women prophets at Corinth and many who assisted Paul. $^{27}$

Prophecy was also central to Luke's story of Christianity; Elizabeth was filled with the Holy Spirit and gave a prophetic witness to how special Mary would be and the uniqueness of Mary's child. Mary prophesied in the Magnificat, yet neither one of them was called a prophet. $^{28}$

Women have always played a role in the Church - in my own view, a pivotal, role in helping the spread of Christianity in the early days of the Church. For example, at the beginning of the first century $\mathrm{AD}$, society was very much patriarchal and women were regarded as little else than assets. However, Christ changed all that. He gave women freedom by using them as often as he could in his parables. Paul expressed it so well when he stated in Galatians 3:27-28: For all of you who were baptized into Christ have clothed

\footnotetext{
23 Karen Jo Torjesen, When Women Were Priests. San Francisco: Harper Collins Publishers, 1995:10.

24 Torjesen, p.10

25 Torjesen, p.16

26 Torjesen, When Women Were Priests, p.11.

27 Torjesen, p.23.

28 Torjesen, p. 26
} 
yourselves with Christ. In Christ there is neither bond nor free, Jew nor Greek, male nor female. There were several women who were patrons to Paul as well - such as Phoebe, Joanna, and Mary of Magdala, etc. ${ }^{29}$

Even though the well-known Gospels were supposedly written by men, we do not know of all the Gospels that women may have written about Christ, which male historians may have suppressed. But Mark's Gospel, supposedly the first of the Gospels to be written, stated that Jesus had women disciples - Mark 15:40 tells us that at the crucifixion, there were also women looking on from a distance. This was a group of women who had provided for Jesus out of their meagre means and who followed Him to Calvary and watched Him dying; and from Calvary they went to the Tomb to anoint the bruised and battered body of their Lord. They were heartbroken when they did not find His body. However, they were rewarded when Christ appeared before them. The Risen Lord appeared firstly to women, and some of these women we know by name: Mary Magdalene, Salome and Mary, the Mother of James and John.

\section{Conclusion: Women in the Church and CAC Today}

What does this have to do with the CAC or women in the church today? It is surprising to this writer that in many denominations, the contributions of women have been relegated to the background. The first Christian Church - the Catholic Church - does not allow the ordination of women.

In June 2011, Apostle Dr Stephen K Amoani, Chairman of the Christ Apostolic Church International (CACI) and eight members of the Church's Executive Council were inducted into office at a ceremony in Accra. They are to steer the affairs of the Church for the next four years. There are four male Apostles but no female Apostles. The only female in the Executive Council is the Director of Finance. Where are the women Apostles?

During a visit to CACI in December 2010, I asked this question and was informed that three women would be ordained in July of the following year but I am not sure if this happened because that information is not posted on the website. When we were leaving, one lady made the comment that someone has to speak for the women in this church because they were being treated as second class citizens. On this visit to CAC International in 2010, I was struck by the absence of women in management.

At a subsequent meeting and presentation on Revivalism at the TIDAC headquarters at Akropong, we were told about the miracle at Asamankese where Apostle Anim and his group, which included two women, all received 'the experience' and they all spoke in tongues; but the men were considered Apostles and not the women - why was that? I was informed that one of the surviving sisters is running the retreat center at Asamankese. Where do women fit into the hierarchy at CACI? An examination of the church leadership shows all Apostles at CACI are men. There are no women Apostles. Yes, the Churches may have women deaconesses, etc. but where does the real power lie? Why are women who speak in tongues; who prophecy as the men, not called Apostles? Why are the men the only ones being given this title?

The Bible has been used to justify so many occurrences both good and evil. It was Christians/Presbyterians who built the first hospital in South Korea but it was also Christians who came to Africa and started the slave trade. Castles and forts that were built

29 Torjesen, p. 33. 
had churches on top of the slave dungeons and they would be having church services while the slaves would be moaning in hunger as well as because of other ailments. It was Christians who came to South Africa and exchanged the Bible for land ownership - so now the natives have the Bible and the white Christians have the land.

Women have always played an important role in the New Testament. As Christians, we are well aware the Jesus supported the marginalized in his time and most of them were women and youth - thus many of Jesus' parables centered on these themes; however, we find that women do not play a major role in the Church today. If we look at the Catholic Church, for instance, women have been relegated to the nunnery with no significant positions in the church; even though there has been speculation that there were women popes in the early church.

Hermeneutics always plays a role in how the reader interprets what he reads; so even though women played a very important role in the early church, the Catholic church has chosen not to adhere to the teachings of Paul as he stated in Galatians 3:28: There is neither Jew nor Gentile, neither slave nor free, nor is there male and female, for you are all one in Christ Jesus.

The Catholic Church is facing its own issues with regards to women and the youth. There was a comment posted on a blog in the August 16, 2010 edition of the Huffington Post by Angela Bonavoglia with the title Women Take on Gender Apartheid in the Catholic Church. Ms Bonavoglia talks about the fact that the two greatest problems the Catholic hierarchy faces are women and children. This article is about actions taken by some women in the Catholic Church to defy the church's ban on women's ordination. All these women were excommunicated by the previous Pope Benedict XVI, who was then Cardinal Joseph Ratzinger.

So where are the women Apostles in CAC today? CAC Worldwide does not have a single woman in their leadership past or present; not in the ranks of their past or current presidents, not amongst their current or past general superintendents, not amongst the general evangelists or general secretaries - they are all men. Where are the women of CAC Worldwide?

As in the Catholic Church, women in the CAC do not have any important roles in the church. The women of CAC of Ghana and Nigeria are no different than Catholic women. Contributions by women are not deemed to be as important as those by men and this fact has been made obvious in their hierarchy. Where both women and men spoke in tongues and even though the women had the healing power over the men, the men were called Apostles and the women could only rise to the level of deacons. Cultural bias may play a role in determining how the CAC handles women in the church, or one could even attribute this to the patriarchal system or even as some argue, the traditional African leadership practices - so that may be the excuse for the CAC, but what about the Catholic Church? Catholic priests have been instructed to be celibate - and some would argue that those were not the instructions in the Bible - especially in light of the ugly truths that have emerged about the actions of Catholic priests.

The point I am trying to make is that just as the Bible has been used to justify slavery, it has been used to justify a whole lot of other issues as well. This article is to start a dialogue; to question the CAC leadership; to bring to the fore that this issue has been noticed. Church leadership does not only belong to men but to all who can prove they are worthy of those positions. 
Borg and Crossan refer to the cover of Newsweek magazine of 6 May 2002 in their book, The First Paul, which asked "What would Jesus Do?"30 Jesus, who elevated women in his parables because he recognized their place in society as possessions with no say in their life, what would Jesus say? Jesus showed how women 'got his message' in many of his parables. So what would Jesus do if he were to come down now to CAC Worldwide and CAC International where there are no women Apostles or places in leadership? My challenge to both CAC churches is that in order for transformation to occur, women must not only be accepted and their gifts acknowledged, but it must be recognized that women have always had authority within the church leadership; women helped Paul to expand Christianity; as women will help CAC Worldwide and CACI to be able to expand the ministries of both churches - especially in the Diaspora.

If CAC Worldwide intends to only serve Nigerians, they will realize that Nigerian children born in the Diaspora, where women's issues are at the forefront of issues especially within the church, will not accept the lack of women in leadership positions that matter in the church. May they come to this realization quickly and soon if their churches are to flourish beyond their borders. Our youth is very important to us because as the future leaders we need to teach them the right way to go.

I hope CAC Worldwide and CACI will change the way they view women and leadership. I would love to be wrong about this and hopefully someone will educate me on this but as at this point, the two websites have yet to prove me wrong. All the past and present key leadership positions have been held by men.

I used the African proverb "no tree can form a forest": this is because when you go into the forest, one sees all kinds of vegetation. Scientifically, the degree of diversity in an ecological zone (which is essentially a form of natural organization) is an indicator of the health status, vitality or sustainability of the ecological zone. The same is true for human organizations. That is the way of the world - leadership should be representative of the congregation.

I have been concentrating on women but we also need to look at the youth. In Africa, we say that "Children must be seen and not heard" or that "A child who knows how to wash his/her hands will eat with his/her elders" but in those wise sayings - what are the children doing? They are around the older and wiser people and learning by listening. So we need to make way for the youth, as Proverbs 22:6 states: "Train up a child in the way he should go: and when he is old, he will not depart from it". However, if we teach our children that women have no place of leadership in the church, that is what they will follow when they become leaders as well. They are our next generation of leaders. Change is always difficult but as we know, when one door closes, another opens; we need to embrace change as an opportunity to find out what God has in store for us.

Joel Olsteen started his service on 18 December 2011with this story: There were three male travellers who came to a raging river and realized they could not cross the river on their own merit. The first traveller prayed and asked God to make him strong so that he could swim across the river, immediately God gave him strong arms and he was able to swim across the river in two hours. The second traveller asked God to give him the strength and the tools to cross the river. Immediately God gave him the strength and a boat and he was able to row the boat across the river in one hour. The third traveller asked God to give him the strength, tools and the intelligence to cross the river and immediately, God turned

30 Marcus J Borg and John Dominic Crossan, The First Paul, p.1 
him into a woman, who took the map they had and within five minutes walked about 50 yards to a bridge and strolled across the bridge to the other side!

We need to start a dialogue on where the CAC stands in terms of issues concerning women. We have heard of the usual excuses about how the church is doing okay and how the church has grown and the fact that the women within the CAC church are happy. What do the women in the CAC church have to say for themselves? The people who are asking for equality in the church leadership are not a minority. The church should realize that women's issues are at the fore especially in the Diaspora and in as much as CAC has churches all over the Diaspora, what do they have to say if someone were to ask - why are there no women in your leadership circle?

What would Jesus do, or better yet, what would Christ say to the leaders of CACI and CAC Worldwide? As stated earlier, one tree cannot form a forest. I believe these churches need all the women in order to achieve the transformation in the Diaspora and sustainability in the long run. What would Jesus do? What would Jesus say?

\section{BIBLIOGRAPHY}

Abalos, David T 1996. Strategies of Transformation toward a Multicultural SocietyFulfilling the Story of Democracy. Westport, CT: Praeger Publishers.

Adegboyega, SG 1991. Short History of the Apostolic Church in Nigeria, 1978:135. cf. IJ Vaughan. Nigeria: Origins of Apostolic Church Pentecostalism.

Akinwumi, Elijah Olu, n.d. . "Dictionary of African Christian Biography" www.dacb.org/stories/nigeria.

Akufo, Kwabena Dautey 2006. Utter Mysteries To God: The Power in Holy Spirit Baptism and Tongues. Massachusetts: Xulon Press.

Anim Peter, n.d. The History of How the Full Gospel Church was founded in Ghana. Accra: CAC.

Amoah, Elizabeth, \& Mercy Amba Oduyoye 2002. When Silence Is No Longer An Option. Accra-North: Sam-Woode Ltd.

Borg Marcus J, John Dominic Crossan 2009. The First Paul. New York: HarperCollins.

Boulding, Elise 2000. Cultures of Peace: The Hidden Side of History. New York: Syracuse University Press.

Bristow John Temple 1988. What Paul Really Said About Women. San Francisco: Harper \& Row Publishers.

Chiromba, Frederick E 1989. Evangelism and Inculturation. Gweru, Zimbabwe.

Crossan, John Dominic, Jonathan L Reed 2004. In Search of Paul. San Francisco: Harper Collins Publishers.

Eitel, Keith E 1988. "Contextualization: Contrasting African Voices." Criswell Theological Review 2. 323-334.

Fowl, Stephen E 1997. The Theological Interpretation of Scripture:

Classic and Contemporary Readings. Blackwell.

Geertz, Clifford 1973. The Interpretation of Cultures. London: Fontana Press. 
http://scriptura.journals.ac.za

The Role of Women in the Church and in Christ Apostolic Church in Particular

Isichei, Elizabeth 1995. A History of Christianity in Africa. Lawrenceville.

New Jersey: Africa World Press, Inc, Grand Rapids.

Jensen, Lene Arnett 2003. "Coming of Age in a Multicultural World: Globalization and Adolescent Cultural Identity Formation.”Applied Developmental Science 7, no. 3. 197-204.

Korem, Albin K et al. 2004. Traditional Wisdom in African Proverbs.

Accra, Ghana: Publishing Trends.

Levine, Amy-Jill, (ed.) 2003, 2004 respectively. A Feminist Companion to the DeuteroPauline Epistles; A Feminist Companion to Paul. Cleveland: Ohio: Pilgrim Press. 2006. The Misunderstood Jew: The Church and the Scandal of the Jewish Jesus. San Francisco: Harper.

Oduyoye, Mercy Amba 1995. Daughters of Anowa: African Women \& Patriarchy. Maryknoll, New York: Orbis Books.

Peel, JDY 1968. Aladura: A Religious Movement among the Yoruba. London:

International African Institute.

Torjesen, Karen Jo 1995. When Women Were Priests. San Francisco:

Harper Collins Publishers. 